\title{
MODELE DUSZPASTERSTWA W KRAJACH EUROPY ZACHODNIEJ - MODEL NIEMIECKI
}

DOI: http://dx.doi.org/10.12775/TiCz.2020.056

Streszczenie. W artykule zaprezentowano czynniki wpływające na wybór modelu posługi parafialnej w Niemczech. W tym celu przedstawiono stan religijności poszczególnych Kościół w Europie Zachodniej w kontekście wzmagających się prądów sekularyzacyjnych. Następnie omówiono wzorce stosunków państwo-Kościół w Unii Europejskiej, w szczególny sposób zwracając uwagę na sposób finansowania Kościoła w poszczególnych krajach wspólnoty. Na zakończenie przybliżono model duszpasterstwa parafialnego w Kościele niemieckim, który poprzez powyżej wskazane uwarunkowania przeszedł w ostatnich latach proces reorganizacji podstawowych struktur administracyjnych, jakimi są parafie.

Słowa kluczowe: diecezja; duszpasterstwo; finansowanie Kościoła; parafia; prezbiter; restrukturyzacja; sekularyzacja; Unia Europejska.

Abstract. Models of Ministry in the Countries of Western Europe - the German Model. The article presents different factors influencing the choice of parish service model in Germany. For this purpose, the state of religiousness of particular Churches in Western Europe in the context of growing secularisation movements has been presented. Then, the models of relationship between the state and the Church in the European Union have been described, with particular care to the ways of Church funding in particular Member States. In conclusion, the parish ministry model in the German Church - 
a Church which in recent years due to the above-mentioned factors has gone through the process of reorganisation of the parish model - has been illustrated.

Keywords: diocese; ministry; Church funding; parish; presbyter; restructuring; secularisation; European Union.

Gdy zastanawiamy się nad apostolstwem w tradycyjnym tego słowa znaczeniu, to opierając się na Nowym Testamencie i przesłankach teologicznych, możemy powiedzieć, że jest ono zorganizowaną działalnością zbawczą Kościoła, która urzeczywistnia zbawcze dzieło Chrystusa przez udział w jego kapłańskim, prorockim i królewskim urzędzie. Głównym środowiskiem tej aktywności prezbiterów i diakonów są parafie. Duszpasterstwo parafialne ze swej natury jest działaniem uwarunkowanym kontekstem społeczno-politycznym, w którym jest prowadzone. Celem posługi pastoralnej $\mathrm{w}$ parafii jest pomoc $\mathrm{w}$ rozwoju procesu zbawczego zapoczątkowanego przez osobę Chrystusa ${ }^{1}$.

Jego skuteczność w dużej mierze zależy od tego, czy posługa pastoralna odpowiada na współczesne ,znaki czasu”. Decydując o formie modelu duszpasterstwa parafialnego, Kościół musi wziąć pod uwagę mentalność współczesnego człowieka, tak by mógł skutecznie do niego dotrzeć do niego ze swoim przesłaniem. Wymaga to znajomości i zrozumienia świata, w którym żyje współczesny człowiek (KDK 3-4) ${ }^{2}$.

Wybór modelu duszpasterstwa parafialnego adekwatnego do współczesnych uwarunkowań społeczno-politycznych jest jednym z podstawowych zadań teologii pastoralnej. Warto w tym kontekście zapytać o to, jakie czynniki wpływają na wybór modelu posługi pastoralnej. W tym celu konieczne jest przyjrzenie się kondycji religijności katolików w poszczególnych krajach Europy Zachodniej. Następnie należy omówić modele stosunków państwo-Kościół obowiązujące w Unii Europejskiej, w szczególny sposób zwracając uwagę na sposób finansowania Kościoła

${ }^{1}$ R. Kamiński, W. Przygoda, Duszpasterstwo, w: Leksykon teologii pastoralnej, red. R. Kamiński, W. Przygoda, M. Fiałkowski, Lublin 2006, s. 200-201; R. Kamiński, Komplementarność duszpasterstwa i apostolstwa, „Roczniki Teologiczne” 49 (2002) 6, s. 23.

2 G. Potarzyński, „Znaki czasu” w Kościele soborowym, „Życie Katolickie” 4 (1985) 6, s. 88-89. 
w konkretnych krajach. Na koniec zostanie przedstawiony model duszpasterstwa parafialnego funkcjonujący w Kościele niemieckim, który poprzez wyżej wskazane uwarunkowania przeszedł w ostatnich latach proces reorganizacji podstawowych struktur administracyjnych, jakimi są parafie.

\section{RELIGIJNOŚĆ W WYBRANYCH KRAJACH EUROPY ZACHODNIEJ}

Europa uchodzi za jeden z najbardziej zsekularyzowanych obszarów we współczesnym świecie. Nie jest to jednak obszar jednolity. Już od dawno wiadomo, że w różnych krajach starego kontynentu sekularyzacja objawia się na wielu płaszczyznach. W sferze ogólnospołecznej oznacza wyjęcie wielu dziedzin spod wpływów religii, w przestrzeni religijno-instytucjonalnej przejawia się w spadku ilości praktyk religijnych, a w obszarze życia indywidualnego wiernych charakteryzuje się zmniejszeniem oddziaływania religii na życie jednostki ${ }^{3}$.

Badania socjologiczne pokazują, że religijność i kościelność nie są w społeczeństwach europejskich oczywistością kulturową, lecz sprawą indywidualnej decyzji i wyboru. Religijność często przyjmuje formę religijności prywatnej, wyrażającej się postawą „odkościelnienia”, w której wiara niekoniecznie wyraża się w uznaniu autorytetu Kościoła czy w praktykach sakramentalnych ${ }^{4}$. W wielu krajach Europy Zachodniej przejawem sekularyzacji są decyzje o formalnym zerwaniu więzi z Kościołem, czemu towarzyszy dynamiczny wzroście liczby wyznawców islamu ${ }^{5}$ Przyjrzyjmy się zatem, jak powyższe procesy przebiegają w poszczególnych krajach europejskich.

Kościół katolicki w Niemczech jest największą wspólnotą wyznaniową, niemniej jednak liczba katolików w tym państwie nieustannie spada. Według danych konferencji Episkopatu Niemiec w 1990 roku liczba

3 F.X. Kaufmann, Kirche begreifen. Analysen und Thesen zur gesellschaftlichen Verfassung des Christentums, Freiburg im Breisgau 1979, s. 58.

${ }^{4}$ J. Mariański, Religia w społeczeństwie postnowoczesnym, Warszawa 2010, s. $101-102$.

${ }^{5}$ K. Święs, Aktualny kontekst społeczno-kulturowy jako zagrożenie dla wiary, w: Duszpasterstwo wobec kryzysu wiary, red. W. Przygoda, K. Święs, Lublin 2013, s. 57-78. 
wiernych wynosiła 28,2 miliona, w roku 2000 - 26,8 miliona, w roku 2010 - 24,6 mln, a w roku 2017 - 23,5 miliona ${ }^{6}$. Arcybiskup Monachium, kard. Reinhard Marx, odnosząc się do zaistniałej sytuacji, stwierdził, że jest to proces, którego nie można już zatrzymać. Znaczny wpływ na to zjawisko wywarły przemiany, do jakich doszło w sferze religijnej w tym kraju na początku lat 70. XX wieku. Transformacje w przestrzeni wiary interpretowane są jako rezultat procesów społeczno-politycznych poprzedniej dekady, zwłaszcza relatywizmu religijnego i moralnego związanego z działalnością tak zwanego ruchu kontrkultury ' $68^{8}$.

W świetle badań sondażowych postępująca heterogeniczność życia społecznego w Republice Federalnej Niemiec doprowadziła do uniezależnienia społeczeństwa od Kościoła jako instytucji moralnej ${ }^{9}$. Przekłada się ona także na negatywną tendencję odnośnie do praktyk religijnych. Od początku lat 60. można zauważyć zmianę pokoleniową, która uwidacznia się spadkiem uczestnictwa wiernych w praktykach religijnych, zwłaszcza w nabożeństwach niedzielnych ${ }^{10}$. Degresja zwyczajów religijnych ujawnia się jako przejaw utraty wiary. Tam, gdzie Kościół jest identyfikowany

${ }^{6}$ A. Jarecka, Zaskakujące dane: więcej katolików i ewangelików w Niemczech, „dw on-line”, https://www.dw.com/pl/zaskakuj\%C4\%85ce-dane-wi\%C4\%99cejkatolik\%C3\%B3w-i-ewangelik\%C3\%B3w-w-niemczech/a-39848464 (dostęp: 27.12.2018); A. Paprzyca, W co wierza Niemcy? „dw on-line”, https://www.dw.com/pl/w-co-wierz\%C4\%85-niemcy/a-15409273 (dostęp: 27.12.2018).

${ }^{7}$ K. Dahmann, M. Mazanek-Wilczyńska, Kościoły w Niemczech, „dw on-line", https://www.dw.com/pl/ko\%C5\%9Bcio\%C5\%82y-w-niemczech/a-15184385 (dostęp: 27.12.2018).

${ }^{8}$ B. Pasamonik, Fundamentalizm kulturowy jako współczesna kontrkultura. Na przykładzie konwersji na islam, w: Kultury kontestacji. Dziedzictwo kontrkultury i nowe ruchy społecznego sprzeciwu, red. T. Maślanka, R. Wiśniewski, Warszawa 2015, s. 57-72.

9 Zob. R. Inglehart, M. Minkenberg, Die Transformation religiöser Werte in entwickelten Industriegesellschaften, w: Jahrbuch für Europa- und Nordamerika-Studien 2: Religion und Politik. Zwischen Universalismus und Partikularismus, red. H.-D. Meyer, M. Minkenberg, Opladen 2000.

10 Zob. R. Kötter, Identität ohne Abgrenzung: Östliche Religionen, w: Religiöse Vielfalt in Nordrhein-Westfalen. Empirische Befunde und Perspektiven der Globalisierung vor Ort, red. M. Hero, V. Krech, H. Zander, Paderborn 2008; H.-M. Niethammer, Kirchenmitgliedschaft in der Freikirche. Kirchensozlogische Studie aufgrund einer empirischen Befragung unter Methodisten, Göttingen 2005. 
z religijnością, osłabienie kościelności pociąga za sobą także osłabienie religijności ${ }^{11}$.

Jednym z najbardziej zsekularyzowanych krajów Europy jest Republika Francuska, w której obowiązuje neutralność religijno-światopoglądowa państwa. Katolicyzm nie jest religią dominującą w tym kraju. Około milion mieszkańców tego państwa należy do Kościołów protestanckich, 4-5 milionów to muzułmanie, około 500 tys. to buddyści, a 700 tys. to Żydzi. Wzrastają też wskaźniki osób deklarujących się jako niewierzący lub należących do nowych ruchów religijnych. Swoistym „znakiem czasów” będącym konsekwencją długotrwałych procesów migracyjnych jest wzrost wyznawców islamu ${ }^{12}$.

Biskupi francuscy, odnosząc się do posługi pastoralnej w zsekularyzowanym społeczeństwie, określają ją mianem „promieniowania wiary”. Przyjmując do wiadomości „oficjalny laicyzm”, proponują wiernym życie wartościami ewangelicznymi, podkreślając, że chrześcijaństwo może pełnić swoje społeczne funkcje nawet w zsekularyzowanym społeczeństwie. Ponadto ufają, że orędzie ewangeliczne przyjęte przez świeckich przyczyni się do wyjścia religii ze sfery prywatnej, a co za tym idzie przemiany sfery publicznej $^{13}$.

Społeczeństwem, w którym w ostatnich dwóch dekadach nastąpiły gwałtowne przemiany społeczno-polityczne i gospodarczo-kulturowe, jest Hiszpania ${ }^{14}$. Różnorakie transformacje dokonujące się w tym kraju pociągnęły za sobą głębokie przemiany w przestrzeni religijności oraz więzi wiernych z Kościołem. Tylko w latach 1976-1983 zmniejszył się wskaźnik praktykujących katolików z 56\% do 31\%. Choć Hiszpanie z pozytywnie odnoszą się do praktyk jednorazowych, np. chrztu - ponad $80 \%$ z nich chce, by ich dzieci zostały ochrzczone, a jeszcze więcej jest zwolennikami

${ }^{11}$ J. Mariański, Sekularyzacja i desekularyzacja $w$ nowoczesnym świecie. Lublin 2006, s. 53-54.

12 A. Müller, Allmähliche Entspannung statt Neuauflage des „Krieges der beiden Frankreich" - über den Platz der Religinen im öffentlichen Raum in Frankreich, „Jahrbuch für Christlische Sozialwissenschaften" 44 (2003a), s. 73-83.

13 J. Mariański, Sekularyzacja, s. 53-54.

${ }^{14}$ I. Solier, Kościół katolicki w nowej sytuacji politycznej w Hiszpanii, w: Religia - tożsamość - Europa, red. P. Mazurkiewicz, S. Sowiński, Wrocław 2005, s. 196-200. 
ślubu kościelnego ${ }^{15}$, to $\mathrm{w}$ ostatnich latach pogłębił się dystans wiernych wobec Kościoła urzędowego i jego doktryny, zwłaszcza w odniesieniu do norm moralnych. Widać to przede wszystkim w stosunku do moralności, a zwłaszcza sfery życia małżeńskiego, gdzie tylko $21 \%$ respondentów akceptuje kościelny zakaz stosowania środków antykoncepcyjnych. Jeżeli nawet około połowy mieszkańców tego państwa pozytywnie ocenia Kościół od strony społecznej, to zdecydowana większość akceptuje rozdział Kościoła i państwa ${ }^{16}$.

Jednym z państw Europy Zachodniej, w którym katolicyzm zajmuje istotne miejsce w życiu społecznym, jest Republika Włoska. Niemniej jednak religijność mieszkańców Italii dotknięta została w ostatnim czasie kryzysem, choć nieco osłabionym w porównaniu do innych krajów europejskich. W dalszym ciągu większość ludności przynależy do Kościoła katolickiego, a bycie katolikiem jest elementem narodowej tradycji. Badania socjologiczne wskazują jednak na tendencje do przejścia od „religijności kościelnej” do tak zwanej „religijności prywatnej”. Przejawia się to zmniejszającą się liczbą praktyk religijnych, autodeklaracji przynależności do Kościoła czy aprobaty treści wiary. Oceny dotyczące kościoła we Włoszech są ze sobą sprzeczne. Mimo iż prawie 74\% osób uważa Kościół za instytucję, w której Bóg jest obecny, to jednak dla prawie połowy Włochów (45\%) Kościół nie jest jedynym autorytetem duchowym i moralnym. Ponad 35\% ankietowanych próbuje żyć według wskazań Kościoła, tyle samo neguje je w zdecydowany sposób, zwłaszcza gdy chodzi o kwestię moralności małżeńsko-rodzinnej. Praktyki religijne utrzymane są jeszcze na dość wysokim poziomie. Około 31\% ankietowanych deklaruje regularne uczestnictwo w niedzielnej mszy św., 13\% przyjmuje Komunię św. Przynajmniej raz w tygodniu. Prawie połowa wiernych (43\%) jest za utrzymaniem spowiedzi w dotychczasowej formie, jednocześnie co piąty badany nie widzi sensu w spowiadaniu się (19\%), a prawie 30\% preferuje bezpośrednie zwracanie się do Boga bez pośrednictwa prezbitera ${ }^{17}$.

${ }^{15}$ C.C. Saidel, Individuelle Werte: Zentrale Wertvorstellungen der spaniszen Gesellschaft, w: Spanien: Mitten in Europa. Zum Verständnist der spanischer Gesellschaft, Kultur Und Identität, red. C.C. Saidel, A. König, Frankfurt am Main-London 2002(b), s 247-264.

${ }^{16}$ J. Mariański, Sekularyzacja, s. 56-58.

17 Tamże; H. Punsmann, Ambivalenz mit Optimismus. Kontinuitäten und Wandlungen in den 凶ußerungen italienischer Religiosität. „Jahrbuch für Christlische Sozial- 
Analizując powyższe przesłanki odnoszące się do religijności przedstawionych krajów, możemy zauważyć, że Europa Zachodnia, będąca najbardziej zsekularyzowanym kontynentem, nie jest obszarem, w którym dokonuje się zanik religijności. Wprawdzie obserwujemy odejście wiernych od „religijności instytucjonalnej - kościelnej”, jednak równocześnie rozwija się tak zwana „religijność prywatna”.

Analiza powyższych procesów wskazuje, że model duszpasterstwa w poszczególnych krajach Europy musi być dostosowany do potrzeb wynikających ze stanu religijności w danym państwie. Przy wyborze formy posługi pastoralnej $\mathrm{w}$ parafii należy zwrócić także uwagę na to, jaki model stosunków z państwem występuje na danym terytorium. Jest to szczególnie ważne w kontekście finansowania Kościoła.

\section{MODELE STOSUNKÓW PAŃSTWO-KOŚCIÓł W UNII EUROPEJSKIEJ}

Mimo laicyzacji wiara, w tym również chrześcijaństwo, ciągle jeszcze odgrywa istotną rolę w obszarze życia obywatelskiego, publicznego i politycznego ${ }^{18}$. W większym lub mniejszym stopniu religia bądź religie są dziś obecne w debatach publicznych w prawie wszystkich krajów starego kontynentu. Unia Europejska, w skład której wchodzi 28 państw, musi zadawać sobie szereg pytań dotyczących religii. Odnoszą się one także do posługi pastoralnej i dotyczą między innymi takich zagadnień, jak finansowanie Kościołów, duszpasterstwo w wojsku, więziennictwie i służbie zdrowia oraz nauczanie religii $\mathrm{w}$ szkolne ${ }^{19}$. Ze wzajemnego przenikania się państwa i Kościoła w rozmaitych uwarunkowaniach historycznych wykształciły się w Europie trzy modele relacji między nimi: model ostrej separacji między państwem a Kościołem, model autonomii i współpracy oraz model Kościoła państwowego ${ }^{20}$.

wissenschafern" 44 (2003), s. 99-114.

18 Zob. B. Margueritte, Religia i republika. Francuski model stosunków państwo - Kościół, w: Religia - tożsamość - Europa, red. P. Mazurkiewicz, S. Sowiński, Wrocław 2005, s. 177-185.

${ }_{19}$ G. Robberts, W sprawie artykułu kościelnego w Układzie Europejskim - Maastricht II, w: Europa i Kościót, red. H. Juros, Warszawa 1997, s. 112-113.

${ }^{20}$ S. Swoiński, Modele stosunków państwo-Kościół w UE, „Studia Europejskie” 3 (2008), s. $40-41$. 
Model ostrej separacji między państwem a Kościołem występuje przede wszystkim we Francji, która definiuje siebie jako republikę świecką, co implikuje za sobą laickość sfery publicznej. W modelu tym, w sensie czysto prawnym, Kościołowi nie przyznaje się w zasadzie podmiotowości publicznoprawnej, argumentując, że tego rodzaju rozwiązanie jest gwarantem zachowania spokoju społecznego oraz spójności wielokulturowego państwa. Niemniej trzeba zauważyć, że współczesna polityka tego państwa nie jest w pełni antykościelna. Religia traktowana jest wprawdzie jako sfera prywatna, jednak państwo nie tylko zezwala na prowadzenie duszpasterstwa w więzieniach i szpitalach, ale również je współfinansuje. Dotyczy to także nauczania religii ${ }^{21}$. Choć w zasadzie odbywa się ono poza oficjalnym programem, to w praktyce wypracowano rozwiązanie kompromisowe, na mocy którego w jednym umówionym dniu tygodnia uczniowie mają mniej zajęć, dzięki czemu mogą uczestniczyć w lekcjach religii ${ }^{22}$.

Model autonomii i współpracy występuje natomiast w prawie wyznaniowym krajów niemieckojęzycznych, takich jak Niemcy i Austria, romańskich, jak Włochy, Hiszpania i Portugalia, oraz w nowych państwach Unii Europejskiej, takich jak Polska, Litwa czy Słowacja. Opiera się on na odpowiednich zapisach konstytucyjnych, a często na dwustronnych zapisach konkordatowych ${ }^{23}$.

Rozróżniamy dwie odmiany tego modelu. Pierwszą z nich stanowi model Kościoła popieranego, występujący w państwach łacińskich oraz nowych państwach członkowskich Unii Europejskiej². W krajach tych istnieje jeden historycznie ugruntowany, wiodący Kościół, który przynajmniej symbolicznie jest preferowany przez państwo, o czym świadczy m.in. to, że jest wymieniany z nazwy w konstytucjach tych narodów ${ }^{25}$.

${ }^{21}$ G. Zaraziński, Nauczanie religii $w$ szkole. Praktyka europejska na przykładzie wybranych państw, „Katecheta” 3 (2006), s. 70-76.

22 S. Swoiński, dz. cyt., s. 41-43.

${ }^{23}$ W. Góralski, A. Pieńdyk, Zasada niezależności i autonomii państwa i Kościoła w konkordacie Polskim z 1993 roku, Warszawa 2000, s. 11-23.

${ }^{24}$ Zob. J. Dudziak, Gwarancje wolności religijnej w konkordacie zawartym między Stolica Apostolska o Rzeczypospolita Polska w 1993 roku, Tarnów 2002; J. Kurowski, Konkordat polski. Znaczenie i realizacja, Lublin 1999.

25 S. Swoiński, dz. cyt., s. 43-44. 
Drugą odmianą wzajemnych stosunków między państwem a Kościołem jest model uznanych społeczności wyznaniowych - tak zwany model niemiecki. Występuje on między innymi w Niemczech, Austrii i w Belgii. W tym modelu państwo nie podkreśla swoich związków $\mathrm{z}$ jednym określonym Kościołem, bo występuje $\mathrm{w}$ nim więcej niż jedna wspólnota religijna, która na przestrzeni wieków przyczyniła się do budowania jego tożsamości narodowej. Wspólnoty te otrzymują od państwa wsparcie finansowe na prowadzoną działalność charytatywną i duszpasterską. W praktyce np. w Niemczech oznacza to, że oba wielkie Kościoły prowadzą znaczną część zakładów opieki społecznej, przedszkoli, poradni rodzinnych czy szpitali. Nauczanie religii jest finansowane przez państwo, natomiast wspólnoty religijne odpowiadają za programy nauczania. Rodzice mogą wypisać dzieci z lekcji religii ${ }^{26}$.

Natomiast model Kościoła państwowego można spotkać w Unii Europejskiej, w państwach o wyraźnych korzeniach protestanckich, albo w prawosławnej Grecji. Relacja między państwem a Kościołem regulowana jest tam poprzez prawodawstwo. Praktyczną konsekwencją tego modelu jest wsparcie finansowe, jakie poszczególne Kościoły uznane za narodowe otrzymują od swoich państw. Przyjmuje ono różne formy - od bezpośredniego wsparcia $\mathrm{z}$ budżetu państwa poprzez zbieranie podatków, po zapewnienie Kościołowi odpowiednich dóbr ziemskich, z których może czerpać dochody ${ }^{27}$.

\section{KOŚCIÓŁ WOBEC NOWYCH WYZWAŃ PASTORALNYCH - MODEL RESTRUKTURYZACJI PARAFII NIEMIECKICH}

Biskupi niemieccy, odnosząc się do problemu laicyzacji, zaniku wiary, selektywności w wyborze zasad moralnych, obojętności na sprawy życia sakramentalnego i kryzysu finansowego, zadeklarowali chęć wypracowania nowego modelu posługi pastoralnej w parafii, który uwzględniałby powyższe trudności. Propozycję rozwiązania powyższego problemu ujęto $\mathrm{w}$ programie nowej organizacji pracy w diecezjach, w którym

${ }^{26}$ Zob. K. Warchałowski, Nauczanie religii i szkolnictwo katolickie $w$ konkordatach współczesnych, Lublin 1998.

${ }^{27}$ S. Swoiński, dz. cyt., s. 45-48. 
zawarto takie postulaty jak zredukowanie struktur terytorialnych oraz wprowadzenie nowej polityki personalnej i finansowej parafii. Decyzją Konferencji Biskupów Niemieckich diecezje wypracowały programy restrukturyzacji posługi pastoralnej, uwzględniające lokalną kondycję duszpasterską. Zmiany te zostały zawarte w dokumencie Mehr als Strukturen... ${ }^{28}$. Według hierarchów potrzeba restrukturyzacji uwarunkowana jest kryzysem, w którym znalazł się Kościół. O stagnacji świadczy m.in. brak powołań kapłańskich, zmniejszająca się liczba katolików świeckich, zanik życia wiary i uczestnictwa w sakramentach, kryzys finansowy oraz niska liczba urodzeń przyczyniająca się do powstania niżu demograficznego ${ }^{29}$. Brak powołań jest od wielu dziesięcioleci jednym z największych problemów Kościoła niemieckiego. Prognostycy wskazują, że trend ten utrzyma się w najbliższym czasie. Konsekwencją tego kryzysu jest brak prezbiterów, co powoduje, że wiele parafii nie ma własnego księdza. Generuje to stan, w którym jeden duchowny musi opiekować się parafiami, w których do tej pory pracowało kilku prezbiterów.

Brak księży wymusza powoływanie tak zwanych jednostek duszpasterskich, skupiających kilka parafii wokół jednego księdza. Konsekwencją tej reorganizacji jest ograniczenie celebracji liturgicznych przy równoczesnym przyroście posiedzeń rad parafialnych czy ekonomicznych. Model parafii, w której jeden duszpasterz pełni funkcję proboszcza w kilku parafiach, prowadzi ostatecznie do likwidacji tych jednostek administracyjnych i zastąpienia ich jedną megaparafią ${ }^{30}$.

Kolejnym problemem wymuszającym restrukturyzację parafii jest malejąca liczba katolików świeckich. W latach 1991-2002 zmniejszyła się ona o 1,7 miliona, co oznacza, że w tym czasie znikło około 100 parafii

${ }^{28}$ Zob. Herausgegeben vom Sekretariat der Deutschen Bischofskonferenz, „Mehr als Strukturen ... Entwicklungen und Perspektiven der pastoralen Neuordnung in den Diözesen”. Dokumentation des Studientages der Frühjahrs-Vollversammlung 2007 der Deutschen Bischofskonferenz, „Arbeitshilfen”, nr 216, Bonn 20 V 2007.

${ }_{29}$ Zob. Herausgegeben vom Sekretariat der Deutschen Bischofskonferenz, „Mehr als Strukturen ... Entwicklungen und Perspektiven der pastoralen Neuordnung in den Diözesen". Dokumentation des Studientages der Frühjahrs-Vollversammlung 2007 der Deut-schen Bischofskonferenz, „Arbeitshilfen”, nr 213 , Bonn 12 IV 2007.

${ }^{30}$ Zob. R. Hartmann, Was kommt nacht der Pfarrgemeinde: Anstöße zur Veränderung der kirchlichen Sozialfelder, „Teologia Praktyczna” 18 (2017), s. 73-82. 
liczących średnio trzy tysiące mieszkańców. Każdego roku ubywa nie tylko katolików pasywnych, ale także świeckich zaangażowanych w ruchy i wspólnoty kościelne.

Dramatycznym doświadczeniem Kościoła niemieckiego jest także utrata świadomości życia wiarą, co pociąga za sobą dystans do praktyk sakramentalnych. Przejawia się to w zaniku uczestnictwa w życiu sakramentalnym, w tym przede wszystkim w Eucharystii oraz w sakramencie pojednania i namaszczeniu chorych. Konsekwencją zaniku tego jest brak powołań kapłańskich i gwałtownie zmniejszająca się liczb katolików świeckich.

Topniejąca liczna wiernych pociąga za sobą kryzys finansowy Kościoła niemieckiego. Zmniejszająca się liczba podatników konkordatowego podatku kościelnego pociąga za sobą kryzys finansowy, który uderza w różnego rodzaju struktury finansowane przez diecezje ${ }^{31}$.

Najdrastyczniejszym problemem społeczeństwa niemieckiego, a co za tym idzie Kościoła w Niemczech, jest niż demograficzny ${ }^{32}$. Do powstania tego problemu przyczyniają się wymienione wcześniej sytuacje, które zmieniają od wewnątrz obraz parafii, a co za tym idzie całych diecezji, destabilizując ogólną sytuację Kościoła w tym kraju ${ }^{33}$.

Kryzys Kościoła w Republice Federalnej Niemiec pociągnął za sobą trudności w posłudze pastoralnej w parafii. Wśród przyczyn tego zjawiska hierarchowie kościelni wymieniają przerost personelu świeckiego zaangażowanego w życie wspólnoty, nadmierną liczbę instytucji związanych $\mathrm{z}$ tą jednostką administracyjną i nadmiar biurokracji w działalności parafialnej ${ }^{34}$.

W parafiach niemieckich można zauważyć spadek liczby katolików świeckich, któremu towarzyszy przerost personelu świeckiego zatrudnionego na etatach w parafiach i instytucjach około kościelnych. Jest on

31 A. Żuk, Restrukturyzacja Kościoła w Niemczech, „Pastores” 39 (2008), s. $142-143$.

32 Zob. F. Genn, Das Zusammenwirken von unterschiedlichen Orten, Formen und Vollzügen der Seelsorge in den vergrößerten pastoralen Räumen, w: „Mehr als Strukturen ..., „Arbeitshilfen”, nr 213, s. 43.

${ }^{33}$ L. Schick, Pfarrei - Kirche vor Ort. Theologisch-kirchenrechtliche Vorgaben und Hinweise zur Pfarrei, w: „Mehr als Strukturen..., „Arbeitshilfen”, nr 213, s. 31-32.

34 A. Żuk, dz. cyt., s. 144. 
widoczny w rozbudowanych strukturach kościelnych. W odniesieniu do liczby prezbiterów diecezje posiadają zbyt wiele parafii wyposażonych we własne rady parafialne, ekonomiczne oraz stowarzyszenia oparte na prawie cywilnym, co przyczynia się do rozrostu biurokracji.

Zmniejszającej się liczbie wiernych towarzyszy przerost instytucji wchodzących w skład diecezji czy parafii. W tym miejscu należy zwrócić uwagę na to, że wiele z nich ma jedynie pośredni związek z Kościołem, wykorzystując przy tym jego nieruchomości. Wskazuje się, że w posiadaniu niemieckich diecezji jest zbyt wiele kościołów, plebanii i domów parafialnych, które trzeba utrzymać, przez co parafie stają się nieefektywne pastoralnie.

Przerostowi instytucji w Kościele niemieckim towarzyszy tak zwany przerost biurokracji. Z trudnością można wyobrazić sobie niemiecką parafię funkcjonującą bez sekretarki zajmującej się sprawami biurowymi. Parafie prowadzące działalność edukacyjną, na przykład przedszkole, oprócz sekretarek potrzebują także sprzątaczki, pomocnika technicznego i księgowego. Parafia staje się wówczas przedsiębiorstwem, w którym pracownicy są zatrudnieni na etatach, co często wzmaga problem finansowej niewydolności ${ }^{35}$.

Kryzys posługi pastoralnej wywołany opisanymi powyżej przyczynami jest w Kościele niemieckim faktem obserwowanym i opisywanym od wielu lat. Zgłębiając zaistniałą sytuację, należy zapytać, jaki model posługi parafialnej powinno się obrać, by parafie spełniały swoją funkcję.

W związku z sytuacją, w jakiej znalazł się Kościół w Niemczech, stworzono programy, które przewidują restrukturyzację poszczególnych parafii, dostosowując ich strukturę do uwarunkowań społeczno-religijnych, w których prowadzona jest posługa pastoralna. W myśl tych wytycznych parafie mają przyjąć jedną z trzech form różniących się od siebie stopniem współpracy ${ }^{36}$.

Pierwszą formą jest tak zwany „Związek parafii” (Pfarreiengemeinschaft). Charakteryzuje się on współpracą w różnych przestrzeniach pastoralnych kilku sąsiadujących ze sobą parafii - na przykład prezbiter z jednej parafii jest odpowiedzialny za przygotowanie do bierzmowania w kilku jednostkach administracyjnych, a inny zajmuje się działalnością

35 L. Schick, dz. cyt., s. 33-34.

36 A. Żuk, dz. cyt., s. 145-146. 
charytatywną. Model ten zapewnia parafiom wchodzącym w skład tej struktury absolutną autonomię administracyjną, prawną i finansową przy optymalnym wykorzystaniu poszczególnych duszpasterzy, którzy obejmują swoją działalnością większą liczbę wiernych ${ }^{37}$.

Drugim modelem jest „Sojusz parafialny” (Pfarrverbünde) polegający na wyłonieniu spośród proboszczów danego wchodzących w skład danego zespołu jednego moderatora, który nadzorowałby pracę innych proboszczów (KPK $526 \$ 1$ ). Swoistą cechą tego modelu jest także powołanie jednej rady parafialnej. Parafie wchodzące w skład danego „sojuszu” zachowują swój status prawny, a troska o dobre wykonanie posługi pastoralnej w każdej z nich spoczywa na jednym moderatorze ${ }^{38}$.

Trzecim wzorcem zreorganizowanej parafii jest tak zwana „Nowa - megaparafia” (Die neu errichtete Pfarrei). Zakłada on, że powyższe modele to etap przejściowy, który powinien doprowadzić do likwidacji mniejszych i niewydolnych parafii oraz erygowania w ich miejsce jednej, nowej magaparafii z jednym proboszczem i mniejszą liczbą wikariuszy parafialnych ${ }^{39}$. Taki model „megaparafii” pociąga za sobą nowe metody posługi pastoralnej posługujących $\mathrm{w}$ niej prezbiterów.

Priorytetem w posłudze pastoralnej prezbitera ma być bliskość w osobistej relacji z wiernym. Szczególną uwagę zwraca się na jego osobiste świadectwo życia duchowego, które ma się stać zaczynem odkrywania wiary przez świeckich zamieszkałych na terenie danej parafii. Relacja z wiernymi winna także przełożyć się na dostępność posługi sakramentalnej, która powinna być sprawowana w godzinach dostępnych dla ogółu wiernych.

Zarządzanie parafią przez prezbitera nie powinno ograniczać się jedynie biurokratycznego aspektu duszpasterstwa, lecz być jego integralną częścią. Biskupi niemieccy zwracają także uwagę na to, że wiele funkcji parafialnych, które dotąd należały do księdza, mogą przejąć dobrze

37 Herausgegeben vom Sekretariat der Deutschen Bischofskonferenz, „Mehr als Strukturen ... “Neuorientierung der Pastoral in den (Erz-)Diözesen. Ein Überblick, „Arbeitshilfen”, nr 216, Bonn 12 IV 2007, s. 11-132.

${ }^{38}$ J. Wanke, Einführung in das Thema des Studientages, w: „Mehr als Strukturen, „Arbeitshilfen”, nr 213, s.

$15-21$.

39 Schick, dz. cyt., s. 36-38; A. Żuk, dz. cyt., s. 145. 
przygotowani świeccy. Ponadto funkcjonowanie parafii w dobie kryzysu ekonomicznego winno opierać się na dobrze zorganizowanym wolontariacie parafialnym, który mógłby przejąć wiele funkcji organizacyjnych. Trzeba jednak dobrze skonkretyzować zakres posługi świeckich, aby stali się współpracownikami proboszcza.

Ważnym elementem wspomagającym posługę prezbitera w parafii są stowarzyszenia, ruchy i wspólnoty religijne. Ich istotnym zadaniem jest ożywienie parafii poprzez dawanie świadectwa życia z Chrystusem. Dokonuje się to przede wszystkim poprzez przygotowanie wiernych do sakramentów, w szczególności do Eucharystii.

Znaczącą rolę w kształtowaniu życia wspólnotowego parafii odgrywają sami prezbiterzy. Autorzy dokumentów Kościoła niemieckiego zachęcają ich, by w swoich diecezjach tworzyli wspólnoty kapłańskie, dzięki którym z ożywioną wiarą będą skuteczniej głosili orędzie Ewangeliczne ${ }^{40}$.

\section{ZAKOŃCZENIE}

Posługa pastoralna w parafii jest ściśle uwarunkowana różnego rodzaju czynnikami społeczno-religijnymi. Jednym z nich jest postępująca laicyzacja przyczyniająca się do powstania kryzysu wiary przejawiającego się zmniejszeniem liczby wiernych, spadkiem praktyk sakramentalnych i pojawieniem się tak zwanej „religijności prywatnej”. Zaistniała sytuacja wymusza na hierarchii kościelnej podjęcie próby reorganizacji duszpasterstwa na poziomie diecezji i parafii. Wdrażane w ostatnim czasie przekształcenia stwarzają przestrzeń do dyskusji odnośnie do ich zasadności czy konsekwencji. Wydaje się jednak, że są one konieczne, by w ciągle zmieniającym się świecie parafia spełniała swoje podstawowe zadania.

\section{BIBLIOGRAFIA}

Dahmann K., Mazanek-Wilczyńska M, Kościoły w Niemczech, „dw on-line”, https:// www.dw.com/pl/ko\%C5\%9Bcio\%C5\%82y-w-niemczech/a-15184385 (dostęp: 27 grudnia 2018).

${ }^{40}$ A. Żuk, dz. cyt., s. $147-150$. 
Inglehart R., Minkenberg M., Die Transformation religiöser Werte in entwickelten Industriegesellschaften, w: Jahrbuch für Europa- und Nordamerika-Studien 2: Religion und Politik. Zwischen Universalismus und Partikularismus, red. H.-D. Meyer, M. Minkenberg, Opladen 2000, s. 125-138.

Dudziak J., Gwarancje wolności religijnej w konkordacie zawartym między Stolica Apostolska o Rzeczypospolita Polska w 1993 roku, Tarnów 2002.

Góralski W., Pieńdyk A., Zasada niezależności i autonomii państwa i Kościoła $w$ konkordacie Polskim z 1993 roku, Warszawa 2000, s. 11-23.

Hartmann R., Was kommt nacht der Pfarrgemeinde: Anstöße zur Veränderung der kirchlichen Sozialfelder, „Teologia Praktyczna” 18 (2017), s. 73-102.

Herausgegeben vom Sekretariat der Deutschen Bischofskonferenz, „Mehr als Strukturen ... Entwicklungen und Perspektiven der pastoralen Neuordnung in den Diözesen“. Dokumentation des Studientages der Frühjahrs-Vollversammlung 2007 der Deut-schen Bischofskonferenz, „Arbeitshilfen”, nr 213 , Bonn 12 IV 2007.

Herausgegeben vom Sekretariat der Deutschen Bischofskonferenz, „Mehr als Strukturen ... Entwicklungen und Perspektiven der pastoralen Neuordnung in den Diözesen". Dokumentation des Studientages der Frühjahrs-Vollversammlung 2007 der Deut-schen Bischofskonferenz, „Arbeitshilfen”, nr 216, Bonn 20 V 2007.

Herausgegeben vom Sekretariat der Deutschen Bischofskonferenz, „Mehr als Strukturen ..." Neuorientierung der Pastoral in den (Erz-)Diözesen. Ein Überblick, „Arbeitshilfen", nr 216, Bonn 12 IV 2007.

Jarecka A., Zaskakujące dane: więcej katolików i ewangelików w Niemczech, „dw on-line", https://www.dw.com/pl/zaskakuj\%C4\%85ce-dane-wi\%C4\%99cejkatolik\%C3\%B3w-i-ewangelik\%C3\%B3w-w-niemczech/a-39848464 (dostęp: 27 grudnia 2018).

Kamiński R., Duszpasterstwo, w: Leksykon teologii pastoralnej, red. R. Kamiński, W. Przygoda, M. Fiałkowski, Lublin 2006, s. 201-212.

Kamiński R., Komplementarność duszpasterstwa i apostolstwa, „Roczniki Teologiczne” 49 (2002) z. 6, s. 21-33.

Kaufmann F.X., Kirche begreifen. Analysen und Thesen zur gesellschaftlichen Verfassung des Christentums, Freiburg im Breisgau 1979.

Kötter R., Identität ohne Abgrenzung: Östliche Religionen, w: Religiöse Vielfalt in Nordrhein-Westfalen. Empirische Befunde und Perspektiven der Globalisierung vor Ort, red. M. Hero, V. Krech, H. Zander, Paderborn 2008.

Kurowski J., Konkordat polski. Znaczenie i realizacja, Lublin 1999.

Margueritte B., Religia i republika. Francuski model stosunków państwo - Kościół, w: Religia - tożsamość - Europa, red. P. Mazurkiewicz, S. Sowiński, Wrocław 2005.

Mariański J., Religia w społeczeństwie postnowoczesnym, Warszawa 2010.

Mariański J., Sekularyzacja i desekularyzacja w nowoczesnym świecie, Lublin 2006.

Müller A., Allmähliche Entspannung statt Neuauflage des „Krieges der beiden Frankreich” - über den Platz der Religinen im öffentlichen Raum in Frankreich, "Jahrbuch für Christlische Sozialwissenschaften” 44 (2003a), s. 73-83. 
Niethammer H.M., Kirchenmitgliedschaft in der Freikirche. Kirchensozlogische Studie aufgrund einer empirischen Befragung unter Methodisten, Göttingen 2005.

Paprzyca A., W co wierzq Niemcy? „dw on-line”, https://www.dw.com/pl/w-co-wierz\%C4\%85-niemcy/a-15409273, (dostęp: 27 grudnia 2018).

Pasamonik B, Fundamentalizm kulturowy jako współczesna kontrkultura. Na przykładzie konwersji na islam, w: Kultury kontestacji. Dziedzictwo kontrkultury i nowe ruchy społecznego sprzeciwu, red. T. Maślanka, R. Wiśniewski, Warszawa 2015, s. 57-72.

Potarzyński G., „Znaki czasu” w Kościele soborowym, „Życie Katolickie” 4 (1985) nr 6, s. 85-105.

Punsmann H., Ambivalenz mit Optimismus. Kontinuitäten und Wandlungen in den Äußerungen italienischer Religiosität. „Jahrbuch für Christlische Sozialwissenschafern" 44 (2003), s. 94-114.

Robberts G., W sprawie artykułu kościelnego w Układzie Europejskim - Maastricht II, w: Europa i Kościót, red. H. Juros, Warszawa 1997, s. 111-119.

Saidel C.C., Individuelle Werte: Zentrale Wertvorstellungen der spaniszen Gesellschaft, w: Spanien: Mitten in Europa. Zum Verständnist der spanischer Gesellschaft, Kultur Und Identität, red. C.C. Saidel, A. König, Frankfurt am Main-London 2002(b), s 109-136.

Schick L., Pfarrei - Kirche vor Ort. Theologisch-kirchenrechtliche Vorgaben und Hinweise zur Pfarrei, w: „Mehr als Strukturen ..., „Arbeitshilfen”, nr 213, s. 22-38.

Solier I., Kościół Katolicki w nowej sytuacji politycznej w Hiszpanii, w: Religia - tożsamość - Europa, red. P. Mazurkiewicz, S. Sowiński, Wrocław 2005, s. 196-200.

Swoiński S., Modele stosunków państwo-Kościół w UE, „Studia Europejskie” 3 (2008), s. 39-52.

Święs K., Aktualny kontekst społeczno-kulturowy jako zagrożenie dla wiary, w: Duszpasterstwo wobec kryzysu wiary, red. W. Przygoda, K. Święs, Lublin 2013, s. 57-78.

Żuk A., Restrukturyzacja Kościoła w Niemczech, „Pastores” 39 (2008), s. 141-150. 